\title{
A pilot project to encourage scientific debate in schools. Comics written and peer reviewed by young learners
}

\author{
Giovanni Lo Iacono, Adélia S.A.T. de Paula
}

\begin{abstract}
Comprehension of the nature and practice of science and its social context are important aspects of communicating and learning science. However there is still very little understanding amongt the non-scientific community of the need for debate in driving scientific knowledge forward and the role of critical scrutiny in quality control. Peer review is an essential part of this process. We initiated and developed a pilot project to provide an opportunity for students to explore the idea that science is a dynamic process rather than a static body of facts. Students from two different schools experienced the process of peer-review by producing and reviewing comics related to the science done at Rothamsted Research. As authors, students showed a large degree of creativity and understanding of the science while as referees they showed good critical skills. Students had at first hand an insight into how science works.
\end{abstract}

\section{Introduction}

The current paper explores a novel approach aimed to enhance the understanding amongst young learners of how scientific ideas are accepted by peers. In this pilot project, students from two different schools experienced the process of peer-review by producing and reviewing comics related to the science done at Rothamsted Research. The project was motivated by the need to promote awareness of how science works, a controversial element in the current science curriculum, and to provide students with a better understanding of the mechanism of peer review. It was also intended to meet needs and interests of young learners by promoting a popular means of communication such as comics.

The pilot project described here gave students the opportunity to experience a key aspect of the daily professional life of scientists while producing comics in teams, to nurture their own creativity and enhance their artistic, communication and critical skills. Sharing the outcomes of this activity might be of interest to the science communication/education community to extend and encourage further research.

\section{Context: Science and society. The importance of understanding the mechanism of peer review to validate scientific evidence}

Modern science depends on critical evaluation (peer review) of evidence to validate claims and quality control publication of results. This process is fundamental for the continuity of science but is conducted within the scientific community. For society at large, the mechanism of peer review is unfamiliar.

Peer review has intrinsic weakness since relies on individual judgment, preferences and openness to new ideas, and may be compromised by competitive interests from researchers working in similar areas. Despite the arbitrariness of this process, peer review still plays a central role in many scientific debates. The recent retraction by The Lancet of Wakefields' study suggesting possible links between MMR vaccine and autism, questioned the integrity of the published peer-reviewed medical research. ${ }^{1}$ Richard Horton, editor of The Lancet said: "the Lancet had done what it could to establish that the research was valid by having it peer-reviewed but that there is a limit to what peer-review can ascertain". In this particular case, the fact that the study was publicized in prestigious peer reviewed journal made the claims more plausible. 
In a recent Peer Review inquiry by the Science \& Techonology Committee, academics and science organizations submitted written evidence on the merits and problems of this system (see report from Science $\&$ Technology Committee ${ }^{2}$ and references therein). Alternative systems have been proposed (e.g. double blind peer review when both authors and reviewers are anonymous, open peer review when the reviewers are named, electronic database for preprints of scientific papers ${ }^{3}$ where manuscripts are not peer reviewed but made, in general, publicly available before they are published in peer-reviewed journals). Despite this debate, peer review remains the main system for evaluation of scientific research.

At present, most knowledge of science is gained at school, but until recently the emphasis was mainly on facts rather than the scientific process. The publication of the report Beyond $2000^{4}$ brought up the discussion about the form of science education that was offered in the UK in the last decades. A key issue reviewed was what is necessary to prepare young people for today's society. The report stated that science education should: a) attend the needs and interests of young people, b) prepare individuals with a broad general education, communication skills and adaptability, c) develop students capability to engage in science and scientific debates, d) equip individuals to recognise ethical and moral implications of the choices that science offers. Considering the inadequacy of some curricula to provide such knowledge and skills, several important recommendations were made. In line with these recommendations, recent educational changes in the UK science curriculum emphasises the understanding of How Science Works, in particular "how uncertainties in scientific knowledge and scientific ideas change over time and about the role of the scientific community in validating these changes". 5 The teaching of the new science specifications for 14-16 year olds in England began in 2006 with an intended emphasis on teaching about socio-scientific issues and the nature of science, considered by some as the most radical aspect of the current reform. ${ }^{6}$

\section{Evidence of pedagogical benefits of peer review}

An increasing body of research has emphasized the potential benefits of using peer review in the classroom. Peer review has been proposed as an effective pedagogical tool in a variety of ways: teaching of a second language ${ }^{7}$ or improving writing skills. ${ }^{8,9}$ Iyengar $^{10}$ used a combined arrangement of lectures, journal club and web-based peer activities in order to assess how students integrated their knowledge with depth of reasoning. Similarly, peer assessment (i.e. the simple assessment of student work by other students, rather than argument-counterargument mechanism typical of peer reviews) is becoming an essential part of teaching and learning processes. Frequently used in a school context, peer assessment has been associated with positive effects: beneficial for the learning process ${ }^{11}$ and improving communication, self-evaluation and self-criticism skills. ${ }^{12,13,14}$ Both peer and self-assessment can enhance students learning by reflecting on the quality of their work and how to improve it. This enables children to give each other valuable feedback so they learn from and support each other. It adds a valuable dimension to learning. Trautmann ${ }^{15}$ argues that "despite the primarily goals related to improving students communication and critical-thinking skills, deepening conceptual understanding, increasing motivation and responsibility for their own learning, using peer review as an educational tool can help understanding how the scientific community interacts to construct, revise and disseminate knowledge claims" (Tables 1, 2).

\section{Importance of understanding the needs and interests of young learners}

Research has suggested that more emphasis should be placed on the importance of people taking control of their own learning. Self assessment and peer review can help to enable this change. Davis ${ }^{16}$ says that "as students engage in a more student-centred and "active science" and develop more autonomy around their learning, they will develop habits and identities as life-long learners and engage in science within their communities and, in some cases, as teachers of children" (p. 8). In addition, according to Osborne and Millar report ${ }^{4}$ science education should: a) attend the needs and interests of young people, b) prepare individuals with a broad general education, communication skills and adaptability. This also reflects a line of thought that student's voice should be heard and more recent research focuses on student's opinion about the form, content and purpose of their education. ${ }^{17}$ Reiss ${ }^{18}$ argues that "science education can only succeed when pupils believe that the science they are being taught is of personal worth to themselves." Beyond 2000 concluded that little emphasis is placed on discussion or analyses of contemporary scientific issues in the science curriculum and also that there is a "lack of variety of teaching 


\begin{tabular}{l|l}
\hline $\begin{array}{l}\text { Peer review functions in } \\
\text { professional science }\end{array}$ & Peer review functions in school science \\
\hline $\begin{array}{l}\text { Allocating funding, } \\
\text { journal space, and } \\
\text { opportunity to present at } \\
\text { professional conferences }\end{array}$ & $\begin{array}{l}\text { Motivating students to engage intellectually through presenting } \\
\text { their work to an audience beyond the teacher }\end{array}$ \\
$\begin{array}{l}\text { Improving the quality of } \\
\text { research efforts and } \\
\text { journal publications }\end{array}$ & $\begin{array}{l}\text { Improving student writing through feedback, revision, and } \\
\text { comparison with the work of peers }\end{array}$ \\
$\begin{array}{l}\text { Enhancing credibility and } \\
\text { attempting to increase the } \\
\text { validity of published } \\
\text { results }\end{array}$ & $\begin{array}{l}\text { Enhancing critical-thinking skills through clarifying assertions, } \\
\text { defending arguments, and revising written work }\end{array}$ \\
$\begin{array}{l}\text { Democratizing the } \\
\text { editorial process in } \\
\text { professional journal } \\
\text { publications }\end{array}$ & $\begin{array}{l}\text { Establishing and } \\
\text { maintaining professional } \\
\text { status of journals and their } \\
\text { authors }\end{array}$ \\
\hline
\end{tabular}

Table 1. Functions of peer review in professional vs school science. ${ }^{28}$

and learning experiences leading to many dull and uninspiring lessons. A recommendation that the curriculum should encourage the use of a variety of methods of teaching and the assessment should focus on students capability to understand and interpret scientific information and to discuss controversial issues.

This project was conceived to address these concerns and provide school students with the opportunity to engage with and experience in practise the procedures of peer review.

\section{Comics as a valuable resource for communicating and learning science}

A growing body of research shows that presenting scientific information through stories, novels, comics and plays is an effective tool to transmit scientific knowledge that should be adopted by both science teachers and science communicators (see e.g. Negrete and Lartigue, ${ }^{19}$ Tatalovic $^{20}$ and references therein). Accordingly, an increasing number of initiatives to use comics as a pedagogical tool are now widely available on the Internet. Examples of such online resources and teacher support materials are: the adventure of Selenia developed at Science Communication Unit at University of West England ${ }^{21}$ in the UK, the Comic Book Initiative developed by The Maryland State Department of Education in partnership with Diamond Comic Book Distributors ${ }^{22}$ and the Comics in the classroom ${ }^{23}$ in the USA. In most projects comics are used as an alternative tool to provide information. This has been proved to be an effective way of motivating and engaging students. However the students still play a passive role since they are not involved in the acquisition process and translation of scientific knowledge. 


\begin{tabular}{|c|c|c|}
\hline $\begin{array}{l}\text { Role of peer-reviewing in } \\
\text { the daily practice of } \\
\text { scientists }\end{array}$ & $\begin{array}{l}\text { Role of peer-reviewing } \\
\text { in the current project }\end{array}$ & $\begin{array}{l}\text { Potential pedagogical outcome } \\
\text { of letting pupil discover about } \\
\text { peer-reviewing }\end{array}$ \\
\hline $\begin{array}{l}\text { To evaluate original } \\
\text { research. E.g. novelty of } \\
\text { research, relevance, } \\
\text { accuracy, clarity of } \\
\text { manuscript }\end{array}$ & $\begin{array}{l}\text { To evaluate original } \\
\text { comics. In particular, } \\
\text { originality of the script, } \\
\text { correctness of science, } \\
\text { quality of drawings }\end{array}$ & $\begin{array}{l}\text { By asking students to perform } \\
\text { similar task as real scientists } \\
\text { they have the opportunity to } \\
\text { mimic the daily practice of } \\
\text { scientists }\end{array}$ \\
\hline Possibility of Rejection & $\begin{array}{l}\text { No Possibility of } \\
\text { Rejection }\end{array}$ & $\begin{array}{l}\text { Although rejection of comics } \\
\text { was not contemplated students } \\
\text { had the opportunity to learn } \\
\text { how to cope with criticism, } \\
\text { accepting different perspective } \\
\text { and/or defend their own views } \\
\text { employing an effective exchange } \\
\text { of logical arguments }\end{array}$ \\
\hline Individual Review & Group Review & $\begin{array}{l}\text { In contrast with real science } \\
\text { practice, each review consisted } \\
\text { of the contribution of all } \\
\text { members of a group of students } \\
\text { encouraging collaboration, } \\
\text { communication and critical } \\
\text { skills }\end{array}$ \\
\hline Time Scale & Time Scale & $\begin{array}{l}\text { An additional opportunity to } \\
\text { learn how to deal with tight time } \\
\text { scale }\end{array}$ \\
\hline $\begin{array}{l}\text { Possible help from Peer } \\
\text { or Senior scientists }\end{array}$ & $\begin{array}{l}\text { Help from teacher and } \\
\text { mentors }\end{array}$ & $\begin{array}{l}\text { Students were encouraged to act } \\
\text { independently, but they could } \\
\text { rely on more professional help } \\
\text { from mentors and teachers in all } \\
\text { stage of the project }\end{array}$ \\
\hline
\end{tabular}

Table 2. Analogies/differences between the role of peer-reviewing in the daily practice of scientists and the role of peer-reviewing in the current project.

Encouraging scientific debate. Comics written and reviewed by young learner

In this pilot project, funded by the Biotechnology and Biological Sciences Research Council in the UK (BBSRC) Public Engagement Awards $2009,{ }^{24}$ we provided an opportunity for students to explore the idea that science is a dynamic process, consisting of many falsifiable steps, rather than a static body of facts. Mimicking the practice of peer review, can increase awarness that the so-called "scientific truth" is not a simple, categorigal outcome of an experiment and/or axiomatic-deductive theory, but rather the result of a complex, dialectical process involving an exchange of logical arguments (table 2). Students experienced the process of peer-review having a double role: acting as authors and referees. Students used the language of comics as a technical tool to communicate scientific ideas. As authors, students were expected to understand the underlying concepts of a scientific topic, to process them and to share them in a 
creative way with their peers. They were required to work as a team responsible for the design, text and art work of the comic. As referees they were actively exposed to the role of critical review and argumentation in science. Feedback from referees helps to develop a critical approach, to consider the points of view of others and enhance students ability to defend their own work.

\section{Objectives}

The objectives of the current project were:

- To raise students' awareness of how scientific knowledge is developed and validated by exposing them to the process of peer-review.

- To pro-actively engage students with scientists and interpret and present their research using the medium of comics.

- To promote a range of abilities such as: creativity, communication and critical skills, team work, project management.

\section{Methods}

This pilot project was initially conceived as a novel exercise to introduce students to a key process in science. The project was not designed as a quantitative study to test alternative hypotheses. Instead the activity was intended to assess the value of involving students in interpreting and criticizing scientific information as both producers and reviewers. Therefore we adopted an approach in line with general features of qualitatve reseach methods (see e.g. Hoepfl ${ }^{25}$ ), based mainly on questionnaires, analysis of the material produced by the students, and in part, on qualitative observations of student's response during the activity.

The project involved 35 Key Stage 4 (Ages 14-16 year old) students and teachers from two community girls schools in the UK (Challney High School for Girls in Luton, and Clapton Girls Technology College in Hackney). Both schools have circa 900 students with a large number of girls from minority ethnic backgrounds and a high proportion of girls speaking English as an additional language. The age group was chosen to ensure that the project would not interfere with exams typical of a secondary school. The approach and sample size was to some extent constrained by the time available for extra-curricular activities and the funding provided for the project. The choice of the mentors was based on volunteers but also to ensure a wide representation of the science currently done at Rothamsted. By introducing real scientists to students the project also provided an opportunity to challenge popular science stereotypes. ${ }^{26}$

Students produced a comic that was assessed by peers (referees) from another school. The topics explored how variation, inheritance and evolution impact in modern life, in the context of the bicentenary of Charles Darwins birth in 2009. The students were guided by the mentors to relevant research areas at Rothamsted, such as the development of resistance to pesticides, selection of modern varieties of crops, and mathematical modelling of the evolution or co-existence of different species in contrasting environments.

The students were given clear instructions according to their roles (see supplementary material at Rothamsted Research website ${ }^{27}$ ). As authors, students were asked to produce articles in the format of a comic. Following referees feedback, they were requested to respond to the referees. They had the option to accept referees comments and modify their work accordingly or provide valid arguments to defend their work. Multi-author articles were possible, exploiting the different skills of the authors and encouraging team work. This option was chosen by all students. As referees they reviewed the articles for scientific content, originality and effectiveness in communicating key concepts in evolutionary biology. To ensure that the referees provided clear feedback and precise suggestions they were guided during this process through appropriate questionnaires. ${ }^{27}$

An editorial board consisting of the mentors ensured the correctness of the content. The final output was a magazine containing the comics and extracts of referees comments and authors' response.

A panel consisting of a scientist, a science communicator and an artist selected the best comic to be the cover of the magazine containing all the works produced. See table 3 for more details on the timeline of the project and further discussion for future improvement of the activity. 


\begin{tabular}{|c|c|}
\hline September 2009 & $\begin{array}{l}\text { The project was launched with an induction visit to Rothamsted } \\
\text { Research. Students listened to presentations on the project, key } \\
\text { concepts of evolution and the peer-review process. Each school had } \\
5 \text { groups and for each group we allocated one/two scientists (mentors) } \\
\text { who provided them with some information on a particular topic and } \\
\text { guidelines }\end{array}$ \\
\hline $\begin{array}{l}\text { September-Decemt } \\
2009\end{array}$ & The students planned and designed their comics \\
\hline January 2010 & $\begin{array}{l}\text { The students reviewed the comics. Each group reviewed two comics: } \\
\text { one on the same topic that they produced and another chosen at random }\end{array}$ \\
\hline February 2010 & The students had the opportunity to respond to the comments \\
\hline February 2010 & $\begin{array}{l}\text { The comics were sent to a panel of experts for an evaluation based on } \\
\text { students creativity, ability in communicating the scientific content and } \\
\text { closeness to the guidelines. Each expert provided feedback for each } \\
\text { comic. }\end{array}$ \\
\hline 26 March 2010 & $\begin{array}{l}\text { Students gathered in Rothamsted, the project outputs were presented } \\
\text { and their achievements highlighted. They also had access to experts } \\
\text { feedback. }\end{array}$ \\
\hline
\end{tabular}

Table 3. Timeline of the project.

\section{Results}

\section{Aspects regarding the planning and design of the comics}

In total ten comics were produced, five comics were hand drawn while in the other cases students used computer aided software and images downloaded from the Internet. In some cases the students did not follow the guidelines provided. For example, four groups exceeded the set page limit, one group did not provide summary and in two cases the summary lacked detail. In most cases deadlines needed to be extended. During production of the comics the input of the mentors was limited to some general comments on the summary and the structure of the comics. However, only five groups asked for feedback from mentors.

Except one, all the comics had a very articulated storyline with a range of genres (some comics had a more romantic element, other more tragicomic etc.). Most of the comics had a fictional character involved, e.g. travelling in time, anthropomorphic (with a fish, insects, and weeds acting and feeling like humans) and mythological creatures (vampires).

Students also brought historical and ethical issues to their stories. In three comics we noticed a large degree of autobiographical input; the main characters of the comics are the students themselves (Figures 1), their friends and also the science teacher. In two cases the storyline explicitly related to typical products of popular culture, namely the series Back to the Future by Bob Gale and Robert Zemeckis and Twilight by Stephenie Meyer (Figures 1 and 2). Only one comic had a very descriptive structure limited to a mere explanation of the science, however the quality of the drawing was considered excellent, suggesting that the authors focused more on the artwork rather than the storyline (see Figure 3 ). The students expressed their creativity not only through the script and pictures but also in more subtle ways. For example in one case the authors give a humorous accent to the language of the main character ("No!!! Me crops!!! Ye fungi will pay for this"). In another case the students had an interesting use of alliteration in their title: Fearless Farmer Fights Field of Fungi. 


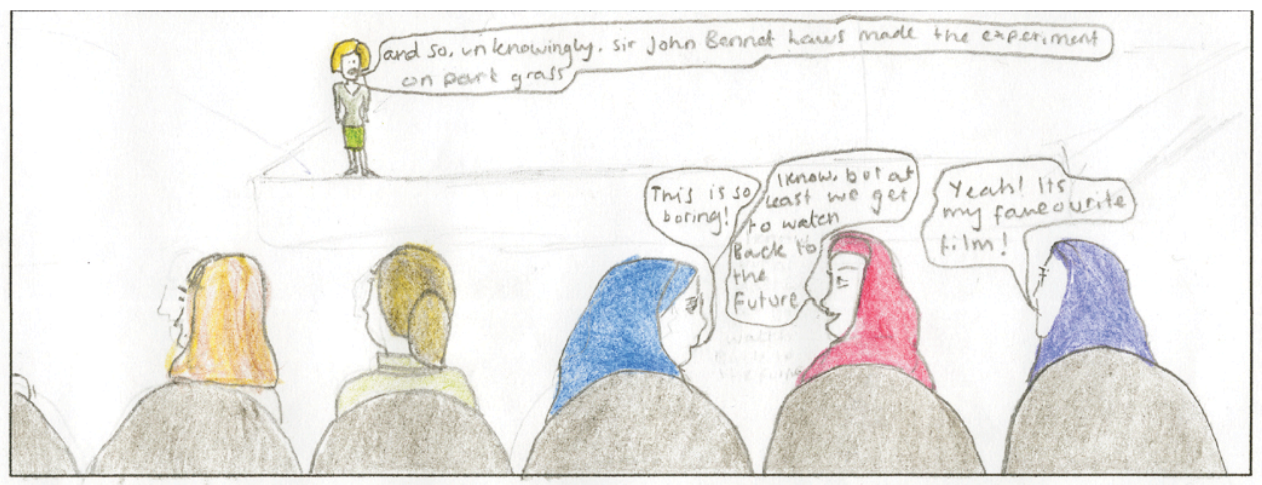

This is us at Rothamsted. As you can see we are finding the experience pretty boring. At least we have the one off premier of Back to the Future to look forward to after this!

Figure 1. The storyline of the comic was inspired by authors' personal experience at Rothamsted during the induction day with reference to a popular movie.

12. The other vampires introduce themselves.
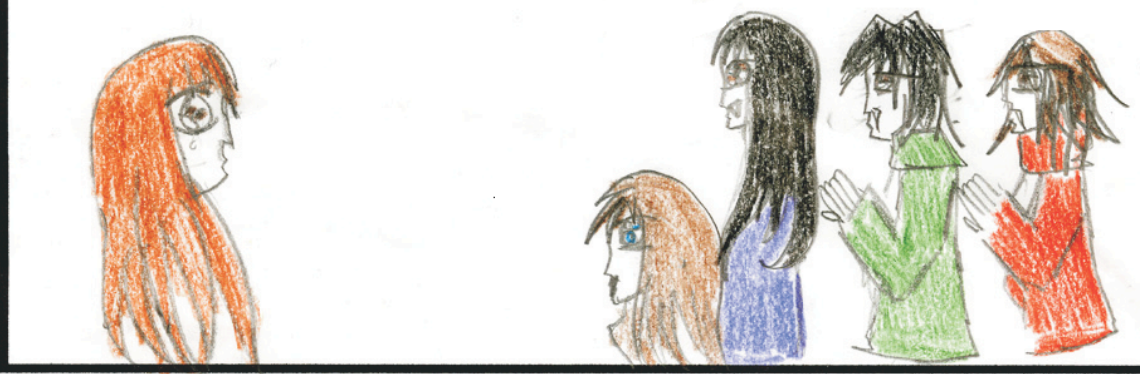

Figure 2. The story incorporates vampires, which seems to be an appealing subject among young people.

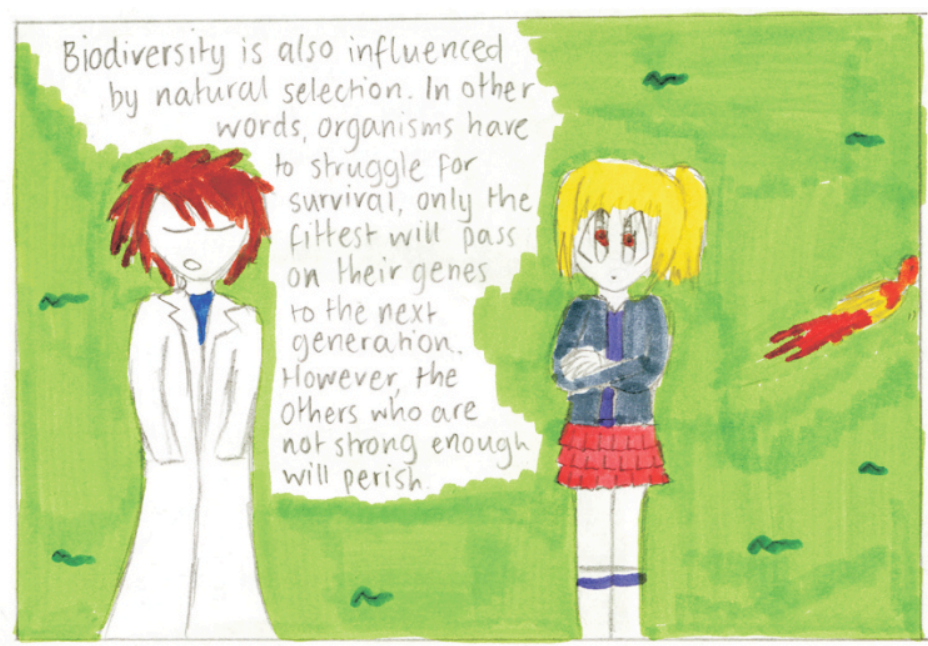

Figure 3. The comic is essentially a conversation between two people, however both referees highly appreciated the quality of the drawings. 
The project also provided an opportunity to challenge stereotyped image ${ }^{26}$ of science by introducing real scientists to students. Despite this, in two comics scientists were represented according to the common Einstein portrait, e.g. white, male, wild-haired loner, madly working. On the other hand, students also took some unconventional decisions, for example in one case the gender of the farmer is female (Figure 4).

In two cases students clearly showed an understanding of comic conventions by varying the box sizes and page grid (e.g. Figure 5).

Perhaps one of the most challenging tasks for the students was to communicate the scientific content in an accurate and effective way. Sometimes the input of science in the comics was limited to a secondary role compared to the artistic input. This was also a frequent point raised by the referees (see below).

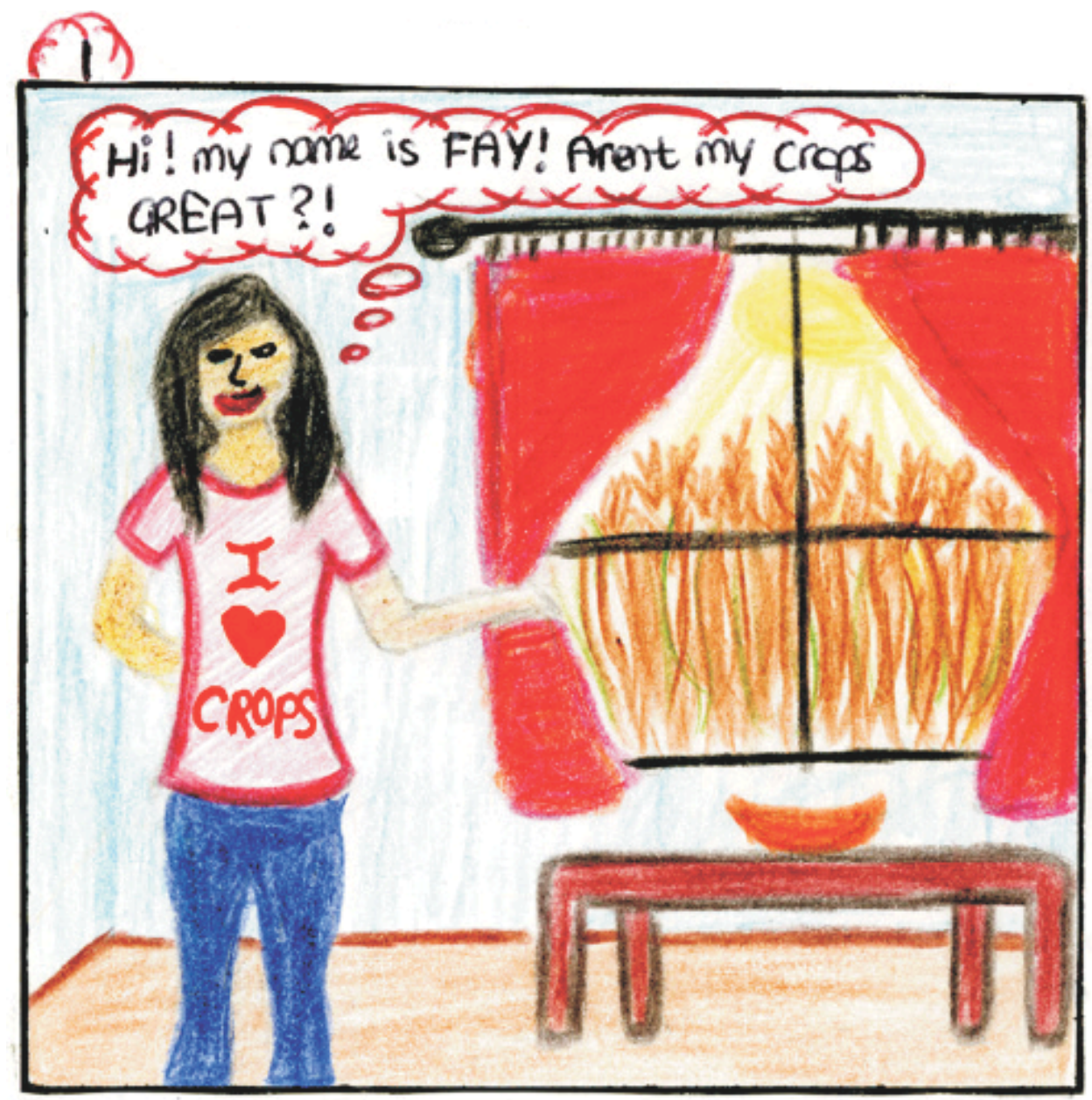

Figure 4. In contrast with many stereotypes, a young woman is presented as a farmer.

\section{The peer review/response process}

Figure 6 shows two examples of peer reviews and responses. An overview of the comments is displayed in table 4 . Five out of ten groups of students explicitly used the template provided. Table 4 also shows the number of cases when the comments of the two referees reports on a particular aspect of the same comic are clearly in conflict. In general, agreement between reviewers was high. We conclude that the guidelines helped the students to address the important, specific points as an experienced reviewer. This is supported by the observation that student's comments were often consistent with feedback from the panel of experts (scientist, science communicator, artist). 

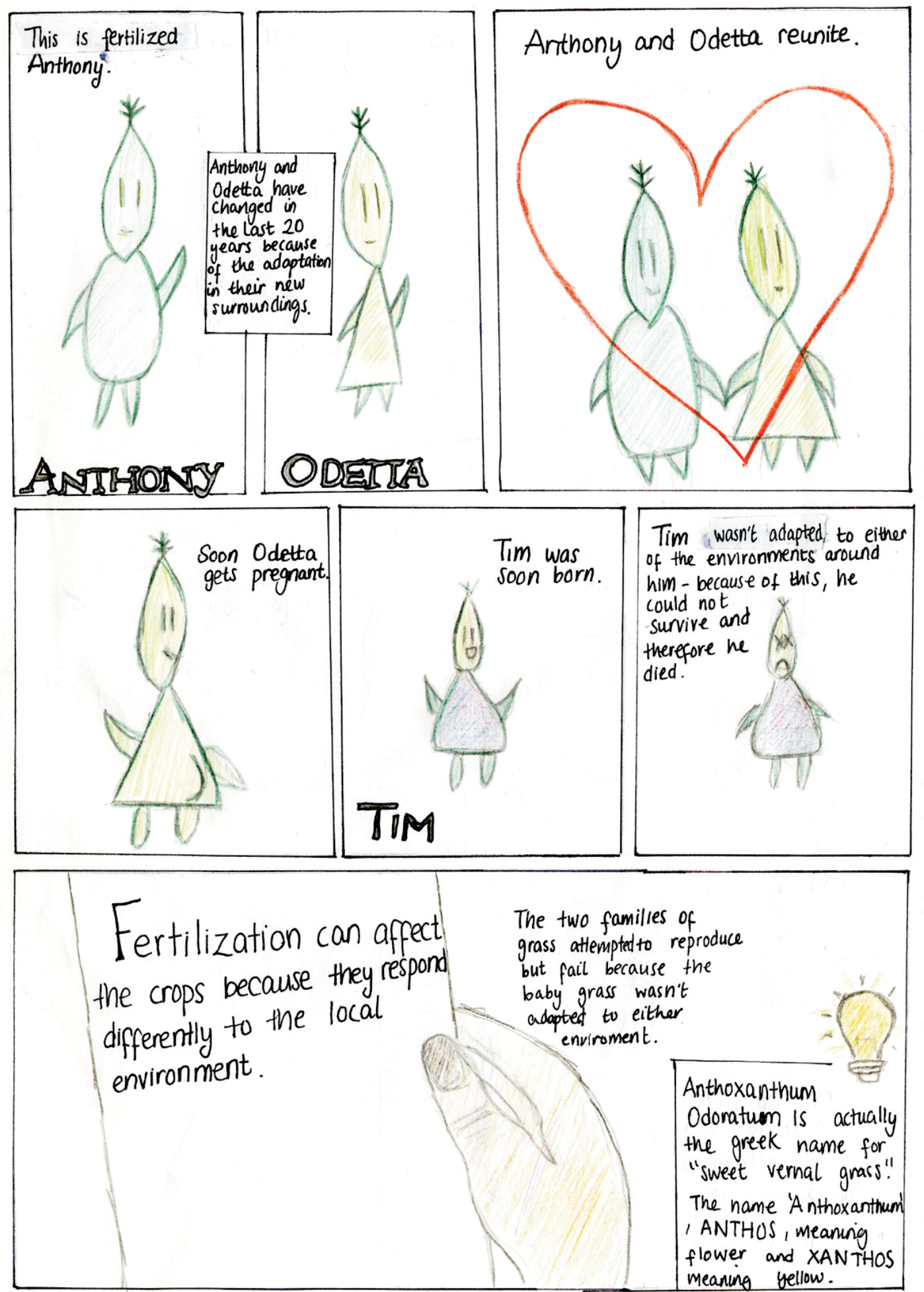

Figure 5. The students made a substantial use of variation of box sizes. 
Referee \#1.

Overall, we appreciated the pictures and colours used for the comic. The bright colours used added description. Also the pictures showed what the authors are trying to put across to the reader. We especially liked the picture of the world with fungi plants on it. The script was a good story. It put across the message well. The quality of the picture with the forces was quite good. It could have been a bit more informative as it doesn't include much science about the topic. Could add an introductory paragraph on the topic it's based on.

Response. We have a little introductory paragraph which links towards the story and the topic, or it touches on the topic, not detailing the whole story, which makes the reader what to read on and find out what the comic is about. We tried to add as much information as possible, but due to the page limit, we were limited to what we could add.

The message that we can take onboard is that there is no point in spraying pesticide as it makes any difference. The pests just reproduce. On the other hand, the innocent insects get killed.

Response. We think that you have misunderstood our message. The point the comic was trying to make was that: to make sure that your crops are 'fungi-free' you should change the fungicide frequently as the fungi mutate so they can withstand the 'current fungicide'. The main objective was to express mutation of fungi and to change fungicides frequently.

\section{Referee \#2.}

Overall we thought the comic was interesting in many ways. However we thought it had some faults, such as the writing in the speech bubbles, we thought it could have been a little larger. We also thought the comic was left in an inconclusive end because it did not tell us who; the fungi or the farmer. The quality of the pictures was very good and we liked the farmers accent, we thought it was amusing. The layout of the comic was well presented and clearly indicated which box to read. The title could have been improved.

Response. Your comments were fairly reasonable and constructive; we have changed the font size so it is now easier to read. However our ending was supposed to end on a CLIFFHANGER (inconclusive end) this relays the message of 'the mutation cycle of fungi' where neither the farmer nor the fungi win! It continues in a never-ending cycle.

Referee \#1.

The story is a little dull and lifeless however the eye-popping computerized graphics more than make up for it. The title is appropriate though they do not talk a lot about the mutating transformation of the bacteria.

Response. The story has humour (boxes 8, 9, 17 etc) and a surprise twist of the surviving superbug (box 9) which adds tension to the story. Furthermore, the 2 wars that take place also give the story 'life.

The title is appropriate though they do not talk a lot about the mutating transformation of the bacteria.

Response. Yes we do. The 10th box is a clear reflection of the mutating transformation of bacteria, and the mathematician in the 12th box also explains this. However, we have taken this aboard and elaborated more in the 12 th box.

Referee \#2.

The overall story was good, the mathematical explanation was clear and easy to understand. The scientific content was good and did not include heavy reading which is a positive factor towards the comic. However the purpose of the antibiotics needs to be elaborated on. You could improve the quality of the pictures and make the animations more interesting by exaggerating some of the characters' features The comic needs to contain well established facts for the reader to be able to take away and remember. This could be achieved by adding a summary box at the end.

Response. There are many well established facts that are explained by the mathematician; for instance, in the 12th box the mathematician explains the differences between the linear and exponential growth of bacteria. However, we have taken aboard your suggestion and added a few more facts in the mathematician's speech.

Overall your strongest point was the mathematical explanation. You need to work on grabbing the reader's attention by putting more interesting facts and making it more attractive.

Response. We made sure that all the images were colourful and attention-grabbing, but the main focus on grabbing the readers' attentions was via humour and the dramatic twist of the surviving bacteria

Figure 6. Two examples of extracts of the referees' comments and the corresponding response from the authors. 


\begin{tabular}{|c|c|c|c|c|}
\hline Key questions & $\begin{array}{l}\text { Number of } \\
\text { reviewers } \\
\text { answering: } \\
\text { YES }\end{array}$ & $\begin{array}{l}\text { Number of } \\
\text { reviewers } \\
\text { answering: } \\
\text { NO }\end{array}$ & $\begin{array}{l}\text { Number of } \\
\text { reviewers } \\
\text { giving NO } \\
\text { ANSWER }\end{array}$ & $\begin{array}{l}\text { Number of } \\
\text { cases when } \\
\text { the reviewers } \\
\text { disagree }\end{array}$ \\
\hline $\begin{array}{l}\text { From reading the comics, } \\
\text { are you able to see any } \\
\text { take home messages? } \\
\text { Can you draw clear } \\
\text { conclusions? }\end{array}$ & 12 & 5 & 3 & 1 \\
\hline Is the title appropriate? & 9 & 8 & 3 & 2 \\
\hline $\begin{array}{l}\text { Can you tell why the } \\
\text { topic is important? }\end{array}$ & 5 & 7 & 8 & 1 \\
\hline $\begin{array}{l}\text { Is the abstract clear and } \\
\text { informative? Does it } \\
\text { reflect what was done in } \\
\text { the comics? }\end{array}$ & 10 & 3 & 7 & 1 \\
\hline $\begin{array}{l}\text { Do you think that the } \\
\text { scientific content was } \\
\text { correct? }\end{array}$ & 15 & 3 & 2 & 0 \\
\hline $\begin{array}{l}\text { Do you think that the } \\
\text { scientific content was } \\
\text { enough? }\end{array}$ & 11 & 0 & 0 & 3 \\
\hline $\begin{array}{l}\text { In terms of script, } \\
\text { pictures and/or both, } \\
\text { would you say that the } \\
\text { comic was } \\
\text { original/interesting? }\end{array}$ & 14 & 6 & 0 & 3 \\
\hline Was it enjoyable? & 10 & 7 & 3 & 3 \\
\hline $\begin{array}{l}\text { How informative was the } \\
\text { comic? Did you learn } \\
\text { something new? }\end{array}$ & 8 & 6 & 6 & 1 \\
\hline
\end{tabular}

Table 4. An overview of the comments of the referees. The last column shows the number of cases when the two referees' reports of the same comic, are in conflict with the corresponding key question.

According to 12 out of 20 reviewers the comics had a clear take home message, but only 5 felt able to identify why the topic was important, and 8 of them did not give a clear answer. Almost half of the reviewers considered the title appropriate, the abstract clear and complete and the comic informative. In general most reviewers (15 out of 20) judged the scientific content correct, although 9 of them expressed the opinion that the scientific information was not sufficient. Among these 4 reviewers provided a rather elaborate argument. For example in one comic the authors imagine that the main character dies because of harmful, mutant bacteria (Figure 6), one of the referee disagrees, quoting their argument "In panel 9, it says 'then however much medicine Ansa took, nothing could work against the new bacteria.' If this was true, then wouldn't everyone be dead, seeing as bacteria constantly mutates." Although the referees did not take account of other scientific points (i.e. bacteria are subjected to a natural mortality and mutant bacteria compete with non-mutant bacteria for resources) they showed a mature way to articulate their argument.

Judging the originality of the comics appears to be the easiest task for the reviewers, 14 found the script and/or the pictures original, and half of them considered the comics enjoyable. Most students found it unfair that some of their fellows did not follow the rules provided. 


\section{How the project was perceived by the students}

A questionnaire for the students was sent to the schools. As illustrated in table 5, all the 17 students that answered the evaluation said that they enjoyed the project, $82 \%$ considered it a good opportunity to meet scientists, 94\% said the project helped them to understand their topic and $63 \%$ said that reviewing helped them to understand more about the topic. There was less agreement regarding the project time management: $29 \%$ considered that the time to produce the comic was inadequate. Interestingly $41 \%$ of the students considered the review of their work as constructive and fair. When asked about their future, $47 \%$ said they had not yet made their career options. 59\% of the respondents said that they are interested in pursuing scientific careers. However, only $6 \%$ considered that this particular project supported their decision on career choice. According to students evaluation, they enjoyed: creating the comics, reviewing, learning about a topic, visiting Rothamsted, meeting more people, meeting scientists, doing a project and using computer graphics. Students also said that reviewing other comics was very difficult as well as coping with the criticisms. Some of the students found it difficult to work to deadlines, guidance and waiting for the exchange of materials.

\begin{tabular}{|c|c|c|c|c|c|c|}
\hline Statement & $\begin{array}{l}\text { Strongly } \\
\text { Agree } \\
(\%)\end{array}$ & $\begin{array}{l}\text { Agree } \\
(\%)\end{array}$ & $\begin{array}{l}\text { Neither } \\
(\%)\end{array}$ & $\begin{array}{l}\text { Disagree } \\
(\%)\end{array}$ & $\begin{array}{l}\text { Strongly } \\
\text { Disagree } \\
(\%)\end{array}$ & $\begin{array}{l}\text { Don't } \\
\text { know } \\
(\%)\end{array}$ \\
\hline I enjoyed the project & 24 & 76 & & & & \\
\hline $\begin{array}{l}\text { Project helped me } \\
\text { understand the topic. }\end{array}$ & 35 & 59 & & & 6 & \\
\hline $\begin{array}{l}\text { Reviewing helped me } \\
\text { to understand more } \\
\text { about the topic. }\end{array}$ & 7 & 56 & 19 & 12 & & 6 \\
\hline $\begin{array}{l}\text { Reviews were } \\
\text { constructive and fair. }\end{array}$ & & 41 & 18 & 23 & 12 & 6 \\
\hline $\begin{array}{l}\text { I understood most of } \\
\text { the explanations. }\end{array}$ & 35 & 53 & 6 & 6 & & \\
\hline Context was engaging. & 12 & 82 & 6 & & & \\
\hline
\end{tabular}

Table 5. An overview of students' evaluation of the project.

\section{Additional outcomes}

Teachers were very supportive and are proposing to use the project in their schools as part of students GCSE coursework assignments, an important element for pupils final grade. The project was well received by many scientists accepting the role of mentors despite most of them having not previously been involved with school activities. They were enthused by the interaction with the students and expressed an interest in developing future projects of this kind.

The material and information for the students (guidelines, templates, summaries etc.) are available on our website and can be easily re-used by Rothamsted and also transferred to other institutions.

\section{Future changes based on the pilot project}

There were some difficulties in keeping to the schedule proposed mainly due to difficulties in organizing both schools visits at the same time. If the project is repeated, we would concentrate efforts on making sure that schools agree with the proposed timetable. Some of the students did not follow the guidelines precisely (e.g. 
number of pages per comic) in spite of this information being given to them as a hard copy and also being available on the project website. We would provide stronger support during initial stages of the development of the comics. The general feedback (from students, mentors, teachers, and coordinators) was that students could benefit from a stronger interaction with their mentors at all stages of the project. We would aim to foster this by encouraging additional visits to schools. The students were encouraged to explore different techniques in producing their comics. These included computer-aided software and downloading images from the Internet. In same cases these images might be subject to copyright restrictions. If we repeated the experience we would provide more emphasis on issues related to copyright law and intellectual property.

\section{Conclusions}

In our view, the project was a valuable, effective and enjoyable activity that fulfilled the following objectives: i) Students had the opportunity to experience the important process of peer review developing their critical skills. ii) In general the students have shown creativity; in most cases they clearly understood the underlying scientific concepts. The high quality of the comics produced shows significant efforts by the students at the design stage.

In this particular pilot project, students showed a general understanding of the scientific concepts proposed by the mentors such as crop protection, identifying and reducing environmental impacts, and exploiting advances in mathematical modelling. The project created opportunities for the students to meet our scientists and other professionals that was highly appreciated.

The results of our qualitative approach are not intended to be generalised like those based on quantitative approaches. Emphasis is placed on the ability of the approach to enrich understanding in the interaction of students and participation in the peer review process. Obviously, the results would benefit by repeating the project using quantitative research methodologies.

We hope that this pilot project can be repeated in the future and extended (e.g. different formats other than comics, more schools, alternative topic). Our ultimate aim is to encourage a longer term, larger scale activity accessible to students that would eventually lead to the establishment of a peer-reviewed journal for young learners. Ideally this would be linked with a wide network of university and research institutes to provide their scientific support through mentoring, visits to laboratories and other engagement types of activities.

\section{Acknowledgments}

Giovanni Lo Iacono and Adélia de Paula would like to thank the Biotechnology and Biological Science Research Council (BBSRC) that funded this project through a Public Engagement Awards 2009 and all the participants involved: the students, Robert Mackenzie (teacher at Challney High School for Girls) and Jessika Chaplan (teacher at Clapton Girls Technology College), Rothamsted scientists (Dr. Hans Cools, Dr. Inez Demon, Dr. Kevin Gorman, Dr. Igor Emelianov, Dr. Jon Storkey, Dr. Stephen Parnell) that worked as mentors and the Visual Communications Unit at Rothamsted for their support.

A special acknowledgement for Prof. Steve Jones, Head of the department of Genetics, Evolution and Environment from the University College London, Dr Emma Weitkamp, a senior lectures in science communication at the University of the West of England and Ms Tina Bolyos, an artist who has been actively involved in public engagement, that helped us to judge the projects.

\section{Notes and references}

1 S. Novella, The Lancet retracts Andrew Wakefields article, Retrieved 07/05/2011, available at: http://www.sciencebasedmedicine.org/?p=3716.

2 R. Horton, In Science \& Technology Committee: Written evidence. Peer review, Retrieved 07/05/2011, available at: http://www.publications.parliament.uk/pa/cm201011/cmselect/cmsctech/writev/856/contents.htm. This volume contains the written evidence accepted by the Science \& Technology Committee for the Peer review inquiry.

3 Open access to eprints in physics, mathematics, computer science, quantitative biology, quantitative finance and statistics, Retrieved at Cornell University Library database, 07/05/2011, available at: http://arxiv.org/.

4 R. Millar and J.F. Osborne editors (1998), Beyond 2000: Science Education for the Future, King's College London, Available at: http://www.kcl.ac.uk/content/1/c6/01/32/03/b2000.pdf.

5 National curriculum in the UK, Retrieved 07/10/2010, available at: http://curriculum.qcda.gov.uk. 
6 I. Banner et al. (2010), The impact of recent reforms in the KS4 science curriculum, School Science Review 92(339): 101-109.

7 G. Hu and S. Lam (2010), Issues of cultural appropriateness and pedagogical efficacy: exploring peer review in a second language writing class, Instructional Science 38(4): 371-394.

8 E. Gragson and J. P. Hagen (2010), Developing technical writing skills in the physical chemistry laboratory: A progressive approach employing peer review, Journal of Chemical Education 87(1): 62-65.

9 Y.-F. Yang (2010), Students' reflection on online self-correction and peer review to improve writing, Comput. Educ. 55(3): $1202-1210$.

10 R. Iyengar et al. (2008), Inquiry learning. integrating content detail and critical reasoning by peer review, Science 319(5867): 1189-1190.

11 P. Davies (2002), Using student reflective self-assessment for awarding degree classifications, Innovations in Education \& Teaching International 39: 307-319.

12 F. Dochy, M. Segers and D. Sluijsmans, The use of self-, peer-and co-assessment in higher education: a review, Studies in Higher Education, page 331350.

13 F. Dochy and L. McDowell (1997), Assessment as a tool for learning, Studies in Educational Evaluation 23: 279-298.

14 V. Todd and J. C. Hudson (2007), Using graded peer evaluation to improve students' writing skills, critical thinking ability, and comprehension of material in a principles of public relations course, Journal of College Teaching \& Learning 4(10): 39-46.

15 N.M. Trautmann (2009), Interactive learning through web-mediated peer review of student science reports, Educational Technology Research and Development 57(5): 685-704.

16 K.S. Davis (2003), Change is hard: What science teachers are telling us about reform and teacher learning of innovative practices, Science Education 87(1): 3-30.

17 E.W. Jenkins (2006), The student voice and school science education, Studies in Science Education 42: 49-88.

18 M. Reiss (2004), Students' attitudes towards science: a long term perspective, Canadian Journal of Science, Mathematics and Technology Education 4(1): 97-109.

19 A. Negrete and C. Lartigue (2004), Learning from education to communicate science as a good story, Endeavour 28(3): 120-4; Negrete, Aquiles Lartigue, Cecilia (2004), Review England Endeavour, Endeavour 28(3):120-4.

20 M. Tatalovic, Student science publishing: an exploratory study of undergraduate science research journals and popular science magazines in the US and Europe, JCOM 07(03): A03.

${ }^{21}$ Selenia, Retrieved 07/10/2010, available at: http://www.sciencecomics.uwe.ac.uk.

22 Diamond comic book distributors, Retrieved 07/10/2010, available at: http://www.marylandpublicschools.org/MSDE/programs/recognition-partnerships/md-comic-book.htm.

23 Comics in the classroom, Retrieved 07/10/2010, available at: http://comicsintheclassroom.net/.

24 BBSRC Public Engagement Awards 2009, Retrieved 07/10/2010, available at: http://www.bbsrc.ac.uk/web/FILES/PreviousAwards/2009 public engagement awards.pdf.

25 M.C. Hoepfl (1997), Choosing qualitative research: A primer for technology education researchers, Journal of Technology Education 9: 47-63.

26 V. Christidou (2006), Greek students' science-related interests and experiences: Gender differences and correlations, International Journal of Science Education 28(10): 1181-1199.

27 Rothamsted Research. Projects for schools, Retrieved 07/10/2010, available at: http://www.rothamsted.bbsrc.ac.uk/schools/Secondary.php?Section=4.

28 N.M. Trautmann (2009), Designing peer review for pedagogical success. what can we learn from professional science?, Journal of College Science Teaching 38(4): 14-19.

\section{Authors}

Dr. Giovanni Lo Iacono is a theoretical physicist by training working at the department of veterinary medicine at the university of Cambridge. His research consists in formulating and applying mathematical models to a range of problems relevant to biology and physics, such as the dispersion of particles in turbulent flows, the searching strategies of animals, the spread of disease and evolution of pathogens. He has a particular interest in public engagement bringing science to society. He conceived the original project idea. E-mail: g1334@cam.ac.uk.

Dr Adélia de Paula is a science communicator working at Rothamsted Research, an agricultural institute founded by the Biotechnology and Biological Sciences Research Council. Adélia has a diverse background with a $\mathrm{PhD}$ in Inorganic Chemistry, working as secondary teacher and University Lecturer and a MA in Science Education. Adélia has a strong commitment to, and experience of, promoting science to different audiences, especially the younger generation.

E-mail: adelia.depaula@rothamsted.ac.uk.

How TO CITE: G. Lo Iacono and A.S.A.T. de Paula, A pilot project to encourage scientific debate in schools. Comics written and peer reviewed by young learners, Jcom 10(03) (2011) A04. 